Gut, 1986, 27, 1213-1218

\title{
Effects of cimetidine on the healing and recurrence of duodenal ulcers and gastric ulcers
}

\author{
M TATSUTA, H IISHI, AND S OKUDA \\ From the Department of Gastrointestinal Oncology and Department of Gastroenterology, The Center for \\ Adult Diseases, Osaka, Japan
}

SUMmaRY The effects of cimetidine on the healing and recurrence of duodenal ulcers and gastric ulcers were compared. The extent of the acid secreting areas was examined by the endoscopic Congo red methylene blue test. Using the extent of acid secreting areas gastric ulcers were classified into ulcers with and without extensive acid secreting areas. Duodenal ulcers were all associated with extensive acid secreting areas. The gastric acid outputs in the basal state and after maximal stimulation with gastrin were highest in duodenal ulcers, and lowest in gastric ulcers without extensive acid secreting areas. Cimetidine treatment significantly promoted the healing of duodenal ulcers and gastric ulcers with extensive acid secreting areas when compared with placebo, but not of the gastric ulcers without extensive acid secreting areas. Cimetidine also significantly diminished the recurrence of duodenal ulcers, but not gastric ulcers with and without extensive acid secreting areas. These findings indicate that in Japan cimetidine promotes the healing of duodenal and gastric ulcers associated with high gastric acid production and prevents recurrence of duodenal ulcers, but has little or no influence on the healing and recurrence of gastric ulcers associated with low acid secretion.

Cimetidine, a histamine $\mathrm{H}_{2}$-receptor antagonist, promotes healing of duodenal ulcers and prevents recurrence of duodenal ulcers. ${ }^{1-3}$ Studies on the effects of cimetidine treatment on the healing and recurrence of gastric ulcers, however, have provided conflicting results. ${ }^{4-10}$ In the present work, therefore, we compared the effects of cimetidine on the healing and recurrence of duodenal and gastric ulcers in relation to the extent of acid secreting areas.

\section{Methods}

\section{PATIENTS}

The effects of cimetidine on the healing and recurrence of duodenal ulcers and gastric ulcers were compared using the endoscopic Congo red methylene blue test. ${ }^{11} 12$ The extent of the acid secreting areas was examined by this test in 87 patients with duodenal ulcers and 177 patients with gastric ulcers. These ulcers were all histologically

Address for correspondence: Masaharu Tatsuta, MD, Department of Gastrointestinal Oncology, The Center for Adult Diseases, Osaka 3-3, Nakamichi 1-chome, Higashinari-ku, Osaka 537, Japan.

Received for publication 27 January 1986 benign. Informed consent was obtained from all patients, and the study was carried out in accordance with the Declaration of Helsinki.

Details of the procedure for the chromoendoscopic examination have been reported elsewhere. ${ }^{11} 12$ In brief, each patient was given proteinases $(20000 \mathrm{U}$ pronase, Kaken Pharmaceutical Co Ltd, Tokyo, Japan) orally 20 minutes before the examination. The patient was then asked to lie on his back, left side, stomach, and right side to remove the gastric adherent mucus. Ten minutes before endoscopy, $4 \mathrm{mg}$ butropium bromide (Coliopan, Eisai Co, Tokyo, Japan) was injected subcutaneously. After placement of the endoscope a spray tube was introduced through the forceps channel, and $0.05 \%$ methylene blue solution was sprayed over the entire surface of the gastric mucosa. After inspection of the surface of gastric mucosa, a mixture of $0.3 \%$ Congo red and $0 \cdot 2 \mathrm{M}$ sodium bicarbonate solution was sprayed over the gastric mucosa, and the blue discolouration of the gastric mucosa with methylene blue examined. An augmented dose of acid secreting stimulant $(5 \mu \mathrm{g} / \mathrm{kg}$ of Tetragastrin-NS, Nissui Pharmaceutical Co Ltd., Tokyo, Japan) was then administered, and acid secretion was observed 
through the endoscope for the next 5 to 20 minutes. Areas over which the Congo red turns blue black owing to acid secretion are designated 'discoloured' areas, while those over which the dye does not change colour are designated 'non-discoloured' areas. In this test, the extent of the acid secreting areas and that of areas of intestinal metaplasia are identified as discoloured areas and areas staining blue with methylene blue, respectively.

The extent of acid secreting areas was classified on the basis of the size of the discoloured areas as follows: (1) Large - discoloured area so extensive that the body of the stomach was completely discoloured. (2) Small - intermediate group showing some, but not complete, discolouration: and (3) None - no acid secretion was detected. The extent of acid secreting areas was judged by one of us (MT) without knowing the patient's treatment. There was no interindividual variation in estimating the extent of the acid secreting areas. The judgements of the size of acid secreting areas by MT and SO were compared in 11 patients in a controlled and blind manner. Two examinations were separated by a period of 1-2 months. Two endoscopists had the same ranks of estimation in all cases.

According to the extent of the associating acid secreting areas, gastric ulcers were classified as gastric ulcers with and without large acid secreting areas. In this series, all duodenal ulcers were associated with large acid secreting areas.

Gastric acid secretions in the basal state and after maximal stimulation with $4 \mu \mathrm{g} / \mathrm{kg}$ of Tetragastrin-NS were evaluated in 21 patients with active duodenal ulcers and 44 patients with active gastric ulcers within less than seven days after chromoendoscopic examination. ${ }^{13}$

The effect of cimetidine on the healing of duodenal ulcers and gastric ulcers was investigated. For this, 45 patients with active duodenal ulcers and 90 patients with gastric ulcers were treated as outpatients and were randomly assigned in a double blind fashion to cimetidine $(200 \mathrm{mg}$ tds after meals and at bedtime) or placebo. The control group received a powdered mixture of $50 \mathrm{mg}$ Scopolia extract, $2 \cdot 0 \mathrm{~g}$ dried aluminum hydroxide gel, and $1.5 \mathrm{~g}$ magnesium oxide per day three times daily 30 minutes after each meal. One gram dried aluminum hydroxide could neutralise $25 \mathrm{mmol}$ of $\mathrm{HCl}$ in vitro test. ${ }^{14}$ Endoscopy was repeated three months after initiation of medical treatment by a clinician with no knowledge of the patient's treatment. Ulcers healing was defined as complete disappearance of the ulcer, and ulcers were recorded as healed or unhealed. Data on five patients with duodenal ulcers and seven with gastric ulcers who did not complete the trial were excluded from the final analysis. Of the 12 patients who failed to complete the trial, eight defaulted or did not comply with instructions, and four declined to undergo a second endoscopy.

The effects of cimetidine on the recurrence of duodenal ulcers and gastric ulcers were examined. Fifty patients with healed duodenal ulcers and 102 patients with healed gastric ulcers were examined. All patients had had an endoscopically diagnosed ulcer within six months of the start of the trial. The patients were randomly divided into two groups in a double blind fashion. They received cimetidine or placebo in the same way as patients with active duodenal or gastric ulcers. Outpatients visited the hospital one every two weeks and their consumption of drugs were noted at each visit. Endoscopy was repeated after three months and at the end of the six month trial, or when the patients had symptoms suggesting ulcer recurrence, by an endoscopist with no knowledge of the patient's treatment. Data on the three patients with healed duodenal ulcers and eight patients with healed gastric ulcers who did not complete the trial were excluded from the final analysis; two defaulted, and nine received less than six months' treatment.

The effects of cimetidine on the healing and recurrence of gastric ulcers located at the angulus were also examined. Another 30 patients with active ulcer and 29 patients with healed gastric ulcer located at the angulus were treated as outpatients with cimetidine $(200 \mathrm{mg}$ tds after meals and at the bedtime). Endoscopy was repeated in the same way as described above. Data on two patients with active ulcers and three with healed ulcers who did not complete the trial were excluded from the final analysis.

Statistical analysis was done with Mann-Whitney $U$ test $^{15}$ or the $\chi^{2}$ test. ${ }^{15}$ The word 'significant' indicates $p$ value of $<0 \cdot 05$.

\section{Results}

CLINICAL DATA ON PATIENTS WITH DUODENAL AND GASTRIC ULCERS

Table 1 summarises the clinical data on patients with active and healed duodenal and gastric ulcers.

There were no significant differences among the groups for age, sex, male to female ratio, or duration of ulcer disease. Gastric ulcers with large acid secreting areas were located chiefly in the antrum or angulus. In contrast, gastric ulcers without large acid secreting areas were located chiefly in the gastric body, although $21 \%$ of them were found in the angulus. Duodenal ulcers were all associated with large acid secreting areas. In contrast, no acid secreting areas were found in $25 \%$ of gastric ulcers without acid secreting areas. 
Table 1 Clinical data on patients with active and healed duodenal and gastric ulcers with and without extensive acid secreting areas

\begin{tabular}{|c|c|c|c|}
\hline Characteristics & $\begin{array}{l}\text { Duodenal } \\
\text { ulcer }\end{array}$ & $\begin{array}{l}\text { Gastric ulcers } \\
\text { with large acid } \\
\text { secreting areas }\end{array}$ & $\begin{array}{l}\text { Gastric ulcers } \\
\text { without large } \\
\text { acid secreting } \\
\text { areas }\end{array}$ \\
\hline $\mathrm{N}$ & 87 & 81 & 96 \\
\hline Men:women & $53: 34$ & $60: 21$ & $72: 24$ \\
\hline Median age yr (range) & $40 \cdot 0(18-62)$ & $42 \cdot 3(20-76)$ & $45 \cdot 5(25-82)$ \\
\hline \multicolumn{4}{|l|}{ Location of ulcer $(\%)$} \\
\hline Duodenum & $87(100)$ & $0(0)$ & $0(0)$ \\
\hline Antrum & $0(0)$ & $38(47)$ & $1(1)$ \\
\hline Angulus & $0(0)$ & $40(49)$ & $20(21)$ \\
\hline Lower corpus & $0(0)$ & $3(4)$ & $23(24)$ \\
\hline Middle corpus & $0(0)$ & $0(0)$ & $28(29)$ \\
\hline Upper corpus & $0(0)$ & $0(0)$ & $24(25)$ \\
\hline \multicolumn{4}{|l|}{ Extent of acid secreting areas $(\%)$} \\
\hline Large & $87(100)$ & $81(100)$ & $0(0)$ \\
\hline Small & $0(0)$ & $0(0)$ & $81(84)$ \\
\hline None & $0(0)$ & $0(0)$ & $15(16)$ \\
\hline History of ulcers yrs (median, range in parenthesis) & $5 \cdot 1(0-8 \cdot 3)$ & $4 \cdot 1(0-5 \cdot 3)$ & $4 \cdot 2(1-6 \cdot 2)$ \\
\hline \multicolumn{4}{|l|}{ Gastric acid output } \\
\hline $\mathrm{BAO}, \mathrm{mmol} / \mathrm{hr}$ & $2 \cdot 96$ & $1 \cdot 30$ & $0 \cdot 05$ \\
\hline (median, range in parentheses) & $(0 \cdot 50-11 \cdot 69)^{*}$ & $(0-4 \cdot 77) \dagger$ & $(0-1 \cdot 70)$ \\
\hline $\mathrm{MAO}, \mathrm{mmol} / \mathrm{hr}$ & $19 \cdot 44$ & $9 \cdot(12$ & 3.05 \\
\hline (median, range in parentheses) & $(6 \cdot 42-36 \cdot 21) \ddagger$ & $(4 \cdot 56-16 \cdot 73) \S$ & $(0 \cdot 23-6 \cdot 11)$ \\
\hline
\end{tabular}

*The differences between the values for duodenal ulcers and gastric ulcers with extensive acid-secreting areas, and those for duodenal ulcers and gastric ulcers without extensive acid-secreting areas were significant at $\mathrm{p}<0.006$ and $\mathrm{p}<0.0006$, respectively.

$\uparrow$ The difference between the values for gastric ulcers with and without extensive acid secreting areas was significant at $p<0.0124$.

$\ddagger$ The differences between the values for duodenal ulcers and gastric ulcers with extensive acid secreting areas, and those for duodenal ulcers and gastric ulcers without extensive acid secreting areas were significant both at $\mathrm{p}<0 \cdot 00006$.

$\S$ The difference between the values for gastric ulcers with and without extensive acid secreting areas was significant at $p<0 \cdot 00006$.

The acid outputs both in the basal state and after maximal stimulation with gastrin were highest in patients with duodenal ulcer, and lowest in patients with gastric ulcer without extensive acid secreting areas.

HEALING OF DUODENAL ULCERS AND GASTRIC ULCERS

Table 2 summarises the results. In patients with duodenal ulcers and patients with gastric ulcers with extensive acid secreting areas, the healing of ulcers in cimetidine treated patients was significantly greater than in patients receiving placebo, whereas there was no significant difference between the healing of ulcers in cimetidine and placebo treated patients with gastric ulcers without extensive acid secreting areas. As shown in Table 2, in patients treated with cimetidine, the healing of gastric ulcers

Table 2 Effects of cimetidine on the healing of duodenal ulcers and gastric ulcers with and without extensive acid secreting areas

\begin{tabular}{|c|c|c|c|c|c|c|c|c|c|}
\hline \multirow[b]{2}{*}{ Treatment } & \multicolumn{3}{|c|}{ Duodenal ulcer } & \multicolumn{3}{|c|}{$\begin{array}{l}\text { Gastric ulcers with } \\
\text { large acid secreting areas }\end{array}$} & \multicolumn{3}{|c|}{$\begin{array}{l}\text { Gastric ulcers without } \\
\text { large acid secreting areas }\end{array}$} \\
\hline & No. & $\begin{array}{l}\text { No. } \\
\text { healed }(\%)\end{array}$ & $\begin{array}{l}95 \% \\
\text { Confidence } \\
\text { limits }(\%)\end{array}$ & No. & $\begin{array}{l}\text { No. } \\
\text { healed }(\%)\end{array}$ & $\begin{array}{l}95 \% \\
\text { Confidence } \\
\text { limits }(\%)\end{array}$ & No. & $\begin{array}{l}\text { No. } \\
\text { healed }(\%)\end{array}$ & $\begin{array}{l}95 \% \\
\text { Confidence } \\
\text { limits }(\%)\end{array}$ \\
\hline Cimetidine & 24 & $21(88)^{*}$ & $73-100$ & 18 & $12(67) \dagger$ & $45-88$ & 27 & $6(22)$ & $7-38$ \\
\hline Placebo & 16 & 7 (44) & $20-68$ & 20 & $4(20)$ & $3-38$ & 18 & $5(28)$ & $7-48$ \\
\hline
\end{tabular}

*The difference between valuies for patients treated with cimetidine and placebo was significant $(\mathrm{p}<0) \cdot(01)$.

$\dagger$ The differences between values for patients treated with cimetidine and placebo and values for cimetidine treated patients with and without large acid secreting areas were significant (both $\mathrm{p}<0 \cdot 01)$. 
with large acid secreting areas was significantly greater than those without large acid secreting areas.

Table 3 summarises the effects of cimetidine on the healing of gastric ulcers located at the angulus. The healing of ulcers located at the angulus in patients without extensive acid secreting areas was significantly greater than in patients with extensive acid secreting areas.

\section{RECURRENCE OF DUODENAL ULCERS AND GASTRIC} ULCERS

Table 4 summarises the results. Only in patients with duodenal ulcers, did cimetidine treatment prevent recurrence of ulcers significantly more markedly than placebo. In cases treated with placebo, recurrence of gastric ulcers were significantly more frequent in patients without extensive acid secreting areas than in those with extensive acid secreting areas. Cimetidine had no significant influence on the prevention of gastric ulcers, however, either with or without extensive acid secreting areas.

Table 5 also shows that cimetidine had no influence on the prevention of gastric ulcers located at the angulus in patients either with or without extensive acid secreting areas.

Table 3 Effects of cimetidine on the healing of gastric ulcers located at the angulus with and without extensive acid secreting areas

\begin{tabular}{|c|c|c|c|}
\hline $\begin{array}{l}\text { Acid secreting } \\
\text { areas }\end{array}$ & No. & $\begin{array}{l}\text { No. } \\
\text { healed }(\%)\end{array}$ & $\begin{array}{l}95 \% \\
\text { Confidence } \\
\text { limits }(\%)\end{array}$ \\
\hline Large & 16 & $6(38)^{*}$ & $14-61$ \\
\hline None or Small & 12 & $10(83)$ & $62-104$ \\
\hline
\end{tabular}

*The difference between values for patients with and without extensive acid secreting areas was significant $(p<0 \cdot 05)$.
Table 5 Effects of cimetidine on the recurrence of gastric ulcers located at the angulus with and without extensive acid secreting areas

\begin{tabular}{lccc}
\hline $\begin{array}{l}\text { Acid secreting } \\
\text { areas }\end{array}$ & No. & $\begin{array}{l}\text { No. } \\
\text { recurred (\%) }\end{array}$ & $\begin{array}{l}\text { Confidence } \\
\text { limits (\%) }\end{array}$ \\
\hline Large & 12 & $3(25)$ & $1-49$ \\
None or small & 14 & $2(14)$ & $-4-33$ \\
\hline
\end{tabular}

\section{Discussion}

The therapeutic effect of the histamine $\mathrm{H}_{2}$ receptor antagonist cimetidine on duodenal ulcers is now well established, ${ }^{1-4}$ but its effect on gastric ulcer has received less attention. ${ }^{5}$ In addition, trials of the effects of cimetidine treatment on the healing and recurrence of gastric ulcer have provided conflicting results. ${ }^{4-10}$ It has already been reported ${ }^{5} 781617$ that cimetidine treatment accelerates gastric ulcer healing significantly as compared with antacid or carbenoxolone. In contrast, however, many other investigators ${ }^{6}{ }^{18-20}$ reported that cimetidine was only at least as effective as an antacid regimen.

According to the extent of acid secreting areas, we classified gastric ulcers into ulcers with and without large acid secreting areas. Gastric ulcers with extensive acid secreting areas are usually located in the antrum or angulus, and are associated with high secretion of acid. In contrast, gastric ulcers without extensive acid secreting areas are usually located in the gastric body, and are associated with low acid secretion. Clinically, the former did not heal completely after medical treatment, but the latter healed more rapidly although ulcer recurrence was more frequent. ${ }^{21}$ These findings led to the suggestion that there are two different aetiological subpopulations in gastric ulcer. In the present study,

Table 4 Effects of cimetidine on the recurrence of duodenal ulcers and gastric ulcers with and without extensive acid secreting areas

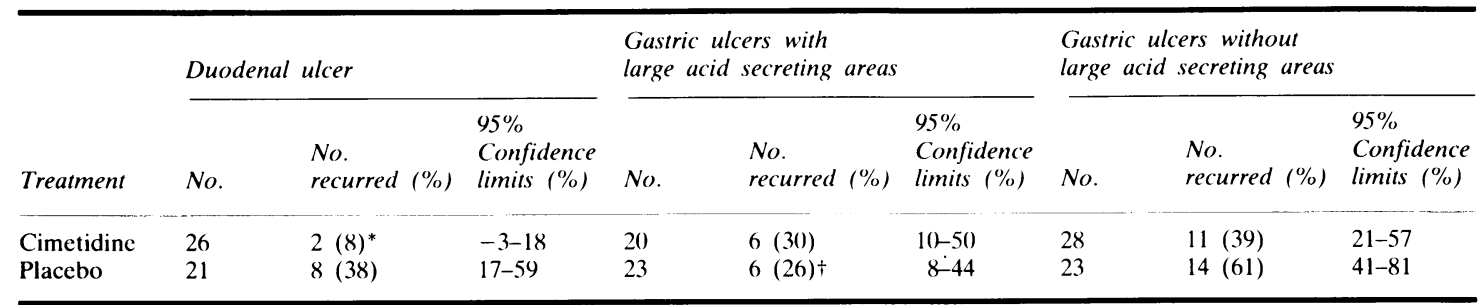

${ }^{*}$ The difference between values for patients treated with cimetidine and placebo was significant $(\mathrm{p}<0 \cdot 05)$.

$\dagger$ The difference between the values for placebo-treated patients with gastric ulcers with and without large acid secreting areas $(p<0 \cdot 05)$. 
we found that cimetidine treatment promoted healing of gastric ulcers with extensive acid secreting areas, but not gastric ulcers without extensive acid secreting areas. The control group received a powdered mixture of $50 \mathrm{mg}$ Scopolia extract, $2.0 \mathrm{~g}$ dried aluminum hydroxide gel, and $1.5 \mathrm{~g}$ magnesium oxide tds. The antacid in this dose promoted the healing of gastric ulcers with low acid secretion. ${ }^{21} 22$ This dose had little or no therapeutic effect, however on the healing of gastric ulcers with high secretion of acid and duodenal ulcer. ${ }^{23}$

As in previous studies, gastric ulcers were not classified in relation to the location of ulcers or the acid secretion, there are only a few reports on the relation of the healing rate of gastric ulcers to these factors. Dyck et al ${ }^{19}$ reported that overall healing appeared to be lowest in hypersecretors and highest in hyposecretors although the differences did not reach statistical significance. They defined the limits of the normal range of MAO as $20-40 \mathrm{mmol}$ per $\mathrm{h}$. In our studies, however, the median and range of the MAO in the patients with gastric ulcers associated with small acid secreting areas were only $3.05 \mathrm{mmol} / \mathrm{h}(0 \cdot 23-6 \cdot 11)$. In the present work, patients were given $4 \mu \mathrm{g} / \mathrm{kg}$ tetragastrin. By means of dose response curves, multicentre study of the Japanese Society of Gastroenterology and Odori showed the appropriate dosage for the maximal acid response to tetragastrin $4 \mu \mathrm{g} / \mathrm{kg}$ by the subcutaneous or intramuscular route. ${ }^{24} 25$ The mean $( \pm$ SEM) of the MAO for healthy subjects has been reported as $9 \cdot 2 \pm 6.9 \mathrm{mmol} / \mathrm{h}$. The MAO in patients with duodenal ulcer and gastric ulcer was approximately $15-20 \mathrm{mmol} / \mathrm{h}$ and $6-12 \mathrm{mmol} / \mathrm{h}$, respectively. ${ }^{26}$ Forst $e t a l^{5}$ reported that with cimetidine corpus ulcers healed significantly more frequently than prepyloric ulcers. They stated, however, that the patients were too few to permit a definitive conclusion. Cimetidine might be expected to be more effective in gastric ulcers with an increased gastric acid secretion than in ulcers with a low acid secretion. In fact, in Japan, Saigenji et $a l^{27}$ and Misaki et $a l^{28}$ obtained results similar to ours. Cimetidine is useful for treating duodenal ulcers with and without gastric ulcers, and gastric ulcers located in the angulus or pyloric antrum.

In gastric ulcers without extensive acid secreting areas, the defensive mechanisms seem to be inadequate to cope with aggression. We found that gastric mucosal blood flow was reduced both in the antral and fundic mucosa in patients with gastric ulcers without extensive acid secreting areas. ${ }^{29}$ These findings indicate that treatment with drugs that enhance the mucosal defensive mechanism is more effective for this type of gastric ulcer than cimetidine.
Prevention of recurrence of gastric ulcers is a more difficult task than healing an active ulcer. Jensen et al, ${ }^{9}$ Hentschel et $a l^{30}$ and Barr et al ${ }^{3 \mathrm{i}}$ reported that maintenance treatment with cimetidine helped to prevent symptomatic relapse in gastric ulcer patients. Similarly, Kikuchi and Miwa ${ }^{32}$ reported that maintenance therapy with cimetidine should be used in patients with increased gastric acid secretion. There are also reports showing the opposite trend, however, as regards recurrence. In the present study, we found that cimetidine treatment could not prevent recurrence of gastric ulcers.

In conclusion, in Japan cimetidine is effective in the treatment of duodenal ulcers and gastric ulcers associated with an increased gastric acid production, but not gastric ulcers with a low acid secretion, and maintenance therapy with cimetidine cannot prevent gastric ulcer recurrence.

\section{References}

1 Blackwood WS, Mandgal DP, Pickard RG et al. Cimetidine in duodenal ulcer. Controlled trial. Lancet 1976; 2: 174-6.

2 Bodemar G, Walan A. Cimetidine in the treatment of active duodenal and prepyloric ulcers. Lancet 1976; 2: 161-4.

3 Domschke W, Domschke S, Lux G et al. Kinetics of duodenal ulcer healing: effects of treatment with cimetidine. Acta Hepato-Gastroenterol (Stuttg) 1976; 23: $441-3$.

4 Freston JW. Cimetidine in the treatment of gastric ulcer. Review and commentary. Gastroenterology 1978; 74: 426-30.

5 Frost F, Rahber I, Rune SJ et al. Cimetidine in patients with gastric ulcer: a multicentre controlled trial. $\mathrm{Br}$ Med J 1977; 2: 795-9.

6 Morgan AG, McAdam WAF, Pacsoo C, Darnborough A. Comparison between cimetidine and Caved-S in the treatment of gastric ulceration, and subsequent maintenance therapy. Gut 1982; 23: 545-51.

7 Pounder RE, Hunt RH, Stekelman M, MiltonThompson GJ, Misiewicz JJ. Healing of gastric ulcer during treatment with cimetidine. Lancet 1976; I: 337-9.

8 Landecker KD, Crawford J, Hunt JH, Gillespie P, Piper DW. Cimetidine and gastric ulcer. A doubleblind controlled trial. Med J Aust 1979; 2: 43-5.

9 Jensen B, Møllmann K, Rahbeck KM, Madsen R, Rune SJ, Wulff HR. Prophylactic effect of cimetidine in gastric ulcer patients. Scand J Gastroenterol 1979; 14: 175-6.

10 Machell RJ, Ciclitira PJ, Farthing MJG, Dick AP, Hunter JO. Cimetidine in the prevention of gastric ulcer relapse. Postgrad Med J 1979; 55: 393-5.

11 Tatsuta $M$, Okuda S, Tamura $H$, Taniguchi $H$. Endoscopic diagnosis of early gastric cancer by the endoscopic Congo red-methylene blue test. Cancer 1982; 50: 2956-60. 
12 Tatsuta $\mathbf{M}$, Iishi $\mathbf{H}$, Ichii $\mathbf{M}$, Noguchi S, Okuda S, Taniguchi $\mathrm{H}$. Chromoendoscopic observations on extension and development of fundal gastritis and intestinal metaplasia. Gastroenterology 1985; 88: 70-4.

13 Tatsuta M, Okuda S. Relation of recurrence of gastric ulcers to fundal gastritis and effect of Gefarnate in preventing recurrence. Endoscopy 1976; 8: 137-41.

14 Nippon Koteishyo Kyokai. Pharmacopoeia Japonica. Edito Deca. Tokyo: Hirokawa, 1981.

15 Seigel S. Nonparametric statistics for the behavioural sciences. New York: McGraw-Hill Book Co, 1956.

16 Barder JP, Morin T, Bernier J et al. Treatment of gastric ulcer by cimetidine. A multicenter trial. In: Burland WL, Simkins MA, eds. Cimetidine: proceedings of the Second International Symposium on histamine $\mathrm{H}_{2}$-receptor antagonists. Amsterdam-Oxford: Excerpta Medica, 1977: 287-92.

17 Hunt RH, Vincent SH, Milton-Thompson GJ et al. Cimetidine in the treatment of gastric ulcer. In: Burland WL, Simkins MA, eds. Cimetidine: proceedings of the Second International Symposium on histamine $\mathrm{H}_{2}$-receptor antagonists. Amsterdam-Oxford: Excerpta Medica, 1977: 293.

18 Ciclitira PJ, Machell RJ, Farthing MJ et al. A controlled trial of cimetidine in the treatment of gastric ulcer. In: Burland WL, Simkins MA, eds. Cimetidine: proceedings of the Second International Symposium on histamine $\mathrm{H}_{2}$-receptor antagonists. Amsterdam-Oxford: Excerpta Medica, 1977: 283-6.

19 Dyck WP, Belsito A, Fleshler B, Lieberman TR, Dickinson PB. Cimetidine and placebo in the treatment of benign gastric ulcer. A multicenter double blind study. Gastroenterology 1978; 74: 410-5.

20 Englert E, Freston JW, Graham DY et al. Cimetidine, antacid, and hospitalization in the treatment of benign gastric ulcer. Gastroenterology 1978; 74: 416-25.

21 Tatsuta M, Okuda S. Location, healing, and recurrence of gastric ulcers in relation to fundal gastritis. Gastroenterology 1975; 69: 897-902.

22 Okada M, Yao T, Fuchigami T, Imamura K, Omae T. Factors influencing the healing rate of gastric ulcer in hospitalised subjects. Gut 1984; 25: 881-5.

23 Tatsuta $\mathrm{M}$, Okuda S, Tamura $\mathrm{H}$. Healing and recurrence of duodenal ulcers in relation to the acid-secreting area. Endoscopy 1982; 14: 11-13.

24 Yamagata S, Masuda $\mathrm{H}$, Ishimoro A et al. Gastric secretion stimulated by gastrin-like AOC-tetrapeptide. Tohoku J Exp Med 1970; 101: 103-17.

25 Odori Y. A clinical and histological study of the gastric secretion induced by gastrin tetrapeptide - with special reference to caffeine method. Jpn J Gastroenterol 1971; 68: $146-59$.

26 Fukutomi H, Shibata H, Sakita T. Peptic ulcer and acid secretion. Clinic All-Round 1978; 27: 432-8.

27 Saigenji K, Yokoyama Y, Mitsuhashi T, Oshida M, Okabe $\mathrm{H}$. The indication and efficacy of $\mathrm{H}_{2}$-receptor antagonist. Stomach Intestine 1984; 19: 499-506.

28 Misaki F, Iwasaki A, Shimada T, Kawai K. How to use the histamine $\mathrm{H}_{2}$-receptor antagonist properly for treatment of peptic ulcer. Stomach Intestine 1984; 507-513.

29 Tatsuta M, Okuda S. Treatment of gastric and duodenal ulcers with cimetidine. [Abstract]. Jpn J Gastroenterol. (In press)

30 Hentschel E, Schütze K, Weiss W et al. Effect of cimetidine treatment in the prevention of gastric ulcer relapse: a one year double blind multicentre study. Gut 1983; 24: 853-6.

31 Barr GD, Kang JY, Canaleso J, Piper DW. A two-year prospective controlled study of maintenance cimetidine and gastric ulcer. Gastroenterology 1983; 85: 100-4.

32 Kikuchi $\mathrm{K}$, Miwa T. $\mathrm{H}_{2}$-receptor antagonist in the prevention of chronic ulcer disease relapse. Stomach Intestine 1984; 19: 521-6. 